\title{
Re-inventing the Future: Linkages between Human Rights, Foreign Policy and Regional Integration
}

\author{
Makumi Mwagiru \\ Institute of Diplomacy and International Studies \\ University of Nairobi \\ director-idis@uonbi.ac.ke
}

Thought and Practice: A Journal of the Philosophical Association of Kenya (PAK)

New Series, Vol.1 No.2, December 2009, pp.73-86

thoughtandpractice@gmail.com OR thoughtandpractice@uonbi.ac.ke

\begin{abstract}
This paper raises questions concerning the emerging trends of regional and international relations. In this endeavour, it examines new insights from traditional perspectives. The paper explores the outer contours of the conceptual linkages between human rights, foreign policy and regional integration in the East African context. Its central argument is that the major debates in the discipline of international relations are ultimately controversies about its theoretical basis.
\end{abstract}

Key Words: international relations, human rights, foreign policy, regional integration, East Africa.

\section{Introduction}

The present paper assesses the ongoing debate on the relevance of international relations in a world that has become increasingly complex. Two levels of this complexity co-exist, sometimes easily, but often uneasily. 
At one level, there are the emerging realities such as the processes of globalization, which have swept all actors in the international system in its wake. In the globalized and globalizing world, there are attempts to assert the universality of certain values and processes, such as those of human rights and theircorresponding standards. But globalization also poses certain urgent problems in the formulation of foreign policies, requiring them to conform, not to the vicissitudes of the doctrinaire past of the Cold War, but to the realities of the complex interdependence in whose grip the international system has found itself.

At the second level, there are questions about the perspectives on which the emerging trends of international and regional relations are based. In examining this second level, we are alive to the principle of reverting to the basics by all sciences whenever they are confronted with disciplinary crises (Hughes 1990, 10), and that at such times traditional perspectives are re-examined, turned on their heads and required to yield new insights. In this regard, emerging realities are confronted, and paradigms, including those which had earlier been considered to have developed significant anomalies, are re-examined on the basis that even they might, in this new future, help in confronting realities which they could not have done earlier.

Those who have been engaged in developing criteria for validity have implicitly accepted the possibilities of the viewpoint above. Karl Popper, for example, conceded that even a theory that had been falsified should not be discarded until a new one arises (Popper 1980, 252; Munz 1985, 224-5). Similarly, Thomas Kuhn (1966) argued that even a paradigm that had developed significant anomalies, and had been overthrown in a scientific revolution, should not be discarded because in the future it might help to solve some puzzles of the day. And for Imre Lakatos (1970), while formulating the notion of progressive and degenerating research programmes, urged that the latter should not be thrown away because they might at a later date yield useful insights that may not have been anticipated. 


\section{Induction, the past, and the future}

The inductivist approach is to generalize from the known to the unknown. However, inductionists have not provided the best criteria for validity by which to judge the state of knowledge in the social sciences in general, and in international relations in particular. Nevertheless, on the basis that one should not throw out the baby with the bathwater, it can be granted that the doctrine of induction might have some redeeming features that could give insight into some conceptual linkages between the triple themes of human rights, foreign policy and regional integration.

Right from independence in the early 1960s until recent years, the repeated experiences of human rights violations in Kenya and Uganda have painted a gloomy picture. Consequently, the question is whether, in terms of its human rights record, the East African region can move from the individualized past into an integrated future in which there is adherence to universally recognized values that define discourse on human rights. The problem perhaps may be, as Bertrand Russell's chicken discovered (Russell 1980, 35), how it can be known that the future will always be like the past. And Russell, or any other owner of a chicken, might well ask why the future must always resemble the past.

In human rights terms, as in other contexts, a possible response could be the realist assertion that the future will always be like the past because it always has been. Despite the temptation to immediately deconstruct realist epistemology in the terms that Vasquez (1983) did so memorably, the uniformity of nature could be accepted as true in terms of the past in the East African human rights realities. Nevertheless, this acceptance may not necessarily hold true for the future, because in a human society which never steps in the same river twice, it cannot be known that the future will be like the past (Abel 1976, 183). To argue that it will be would be to accept human closure, and to accept ultimately that people can never learn from the past.

The doctrine of induction goes this far only, but it is a useful starting point for making conceptual linkages between human rights, foreign policy and regional integration in East Africa. The major theme in the region has been that the foreign policies have by and large 
eschewed any concern for human rights issues, with the possible exception of Tanzania. In the Cold War context, foreign policy was to be conducted with one eye firmly on the tempestuous politics of the period, in which, in arch-realist style, issues of morality were not of the essence, and the domestic was to be completely dichotomized from the international. Equally, the high politics of survival and the unbridled pursuit of national interest was the guiding principle. In that past, foreign policy masked the human rights condition within the region, and was greatly influenced by the harsh requirements of the Cold War era (Stern 2000).

The picture for regional integration is rather different however. Here, induction does not come to the aid of theorizing so easily, because in the inductivist creed, it is not possible to generalize from a single experience. The regional integration experience of the first East African Community was a success while it lasted. Those elements of success in the past might be replicable. However, its collapse, in the past, gives a lesson that East Africans would not want to replicate, because its replication would be replete with pitfalls.

The challenge then is how to understand the process of regional integration that is now underway, but in a manner that does not neglect the implications of the principle of induction. One possibility is to hold the view that the current process of East African integration is essentially an attempt to break from the past; and specifically to break from the implications of East Africa's past in terms of its human rights and foreign policy record. In this sense, the process of integration that is underway in East Africa is an attempt, in practical terms, to make the case that East Africa's future can be, and is being re-invented. The structure for that re-invention is based on rejecting arguments for the uniformity of the nature of past experiences of the East African approaches to human rights, foreign policy and regional integration. Thus here the past is ignored.

\section{Forcing the spring: the new integration}

If the foregoing argument is upheld, the current attempt at regional integration in East Africa can be understood from different standpoints. One of them would be to look at it 
as an attempt to re-create the better experiences of the old East African Community that failed, while avoiding the pitfalls that disturbed that earlier experience. Taking this viewpoint suggests a philosophical belief that the future will always be like the past. In this case, the uniformity of nature that would be suggested is that states and peoples will always look for ways and means of integrating their experiences, their economies and ultimately their politics.

However, present efforts at East African integration could also be seen in the context of expressing the need to meet the demands and requirements of a globalized and globalizing world. In this case, it is accepted that East Africa is not immune from the demands of the processes of globalization, and that it needs to put in place structures that can permit it to reap optimally from the benefits that a globalizing world offers. But here there are two competing viewpoints. First, there is the view that East Africa is already caught up in the fullness of the processes of globalization. Second, there is the belief that East Africans have some way to go to catch up with the globalization train, so that any attempts at institutional building that are evidenced by the new East African Community will essentially be endeavours to help the region catch up with the already globalized world.

The theoretical rationale for the second viewpoint is supported by Modelski's layer cake model of global politics (Modelski 1974). In that model, there are three distinct layers of activity: local, national, and global; a fourth layer, the regional one, has further been aptly suggested by McGrew (1992, 3). The rationale here is that Africa is not yet globalized, but is in the process of globalizing (Harris 2003, 25-6). In the face of this reality, it is necessary for (East) Africa to create regional and other institutions that can help to cushion it against the vicissitudes of the rapid progress of globalization. Institutions such as the East African Community can be understood in this context (Mwagiru 2008a). In this sense, regional integration is merely a plank or a conduit for engaging in the processes of globalization. 
Nevertheless, institutions such as the East African Community can also be seen in the context of regionalizing universalisms such as human rights. This might at one level import the problem of relativism, and hence do harm to the integrity of the universalist discourse, as was the case especially during the Cold War. Yet the issue can also be seen as one of needing a proper translation from one language of discourse (the regional one) to another language of discourse (the universalist), and vice versa (Doyal and Harris 1986). Seen from this perspective, the role of foreign and regional integration policy should be precisely to engage in accurate translation of the two languages of discourse.

The second approach can also be supported by a more "negative" view of the process of globalization. From such a perspective, globalization is not an automatic good that states should pursue uncritically. Instead, it should be understood as having negative effects on the ability of states to maintain the social and economic conditions necessary for the optimal realization of human rights by their citizens. The argument here is that globalization, far from creating the conditions for prosperity for the poor states, actually impoverishes them more, as liberalization policies weaken their wealth creation possibilities, thereby making them unable domestically to create the conditions in which human rights can be realized and thrive (de Senarclens 2003, 149-150).

Current efforts towards regional integration can however be seen from a third, quite distinct standpoint. In this view, the current integration efforts are essentially an attempt to 'force the spring'. This essentially means trying to escape from the inductivist rationale that the future will always be like the past. The past, for East Africa, in both the contexts of regional integration and human rights, is a dark past, replete with all the burdens of winter and gloom, a human rights and integration tsunami from which the region must escape if progress is to be recorded. From this perspective and from the point of view of induction, East Africa's future will resemble the past. But since the past was not so glorious, foreign policy formulation needs to take into consideration policies and institutions that can jump the winter and force the spring of a fully integrated East Africa, marching confidently to not only meet the processes of globalization half way, but also to shape those processes and their attendant debates. If the current regional integration 
attempts can realize this, then it will be possible to assert with some confidence that the future will not be like the past. This indeed will be a statement that East Africa discovered the problems of induction, but in a timelier and less costly way than Russell's chicken did.

\section{Redeeming the future: the human rights dimension}

The inductivist thesis can also be formulated from the perspective of human rights in their international and universal setting. During the Cold War, the idea of universalism could, with some justification, be contested (Hill 1989, 3-4). The imperatives of the Cold War and its ideological and social competitions easily supported this claim. However, the end of the Cold War amongst other things pulled the rug from under the feet of this perspective. Far from entrenching the human rights debate in the context of different generations of human rights on the one hand, and the economic and social conditions necessary for the realization of each of those generations on the other, the post-Cold War understanding of universal human rights is couched more in terms of the democratic institutions that should be universally present in order to create the space for human rights to flourish. These institutions, reflecting the liberal tradition of post-Cold War international relations, involve free and fair elections on the basis of universal suffrage, the rule of law and constitutionalism, and the "protection of those civil and political rights that reasonably protect against the tyranny of the majority" (Forsythe 2000, 13).

In these terms, the human rights and democratic experience of the East African states reveal different patterns of progress. To some extent all the three states can claim to have embraced universalism in different stages in the context of free and fair elections, the rule of law and constitutionalism. Tanzania has gone through its third transition of power since the end of the single party state. Kenya went through its first transition in 2002 since the end of the single party state in 1992, while its second transition in 2007 was only partially successful. Uganda is yet to go through its first transition since 1986 - the year Yoweri Museveni took over power. Of the three states, Tanzania's embrace of universalism in this context is the least contested. Uganda's transition to universalism is heavily contested, because of a prolonged 'no party' policy that was never entirely 
convincing except to the West, and because the democratic character of the last elections was brought into serious question. Kenya's 1992 and 1997 elections were heavily contested (Munene 2001; Chweya 2002); but the 2002 elections and the consequent transition were not contested. Nevertheless, Kenya's 2007 elections were heavily contested, resulting in what was essentially a partial transition (Wanyande, Omosa \& Chweya 2007).

In terms of the second requirement of respect for civil and political rights that reasonably protect against the tyranny of the majority, the record and experiences of the three East African countries is again quite uneven. Here however the discourse is hampered by the inherent difficulties of measuring the extent to which such rights have, in practice as opposed to theory, been protected. The Kenyan case illustrates this quite well. Following the 2002 elections and the coming to power of the new government, there was a climate of hope that the days of the suppression of individual freedoms had come to an end. In theory and even more in political rhetoric, these protections exist; and indeed even in practice, none but the most jaundiced observer can claim that freedoms, like those of expression, are absent. However, protecting civil rights has also much to do with issues of governance and the constitutional structures on which governance is nested. In this regard, the failure of the government to enact a new constitution that would have effectively provided guarantees against the tyranny of the majority means that Kenya's track record has been poor (Mwagiru 2006).

Were East Africa's record to be surveyed from the perspective of induction, in terms of generalizing from repeated observations and raising the issue as to whether the future will be like the past in terms of free and fair elections, the rule of law and constitutionalism on the one hand, and protection of civil and political rights that guard against the tyranny of the majority on the other, the conclusions would be mixed. On the one hand, in terms of the former criteria, the future has not been like the past. On the other, the future will be like the past, particularly on the rule of law and constitutional front. This conclusion is based on the fact that governance in Kenya still rests on the constitutional apparatus of 
the one party state, while in Uganda there has been a manipulative constitutional amendment allowing the president to run for a third term.

On the criterion of protection of civil and political rights that guard against the tyranny of the majority, an inductivist perspective would lead to the conclusion that the future will be like the past. Similarly, the future resembles the past, because the rhetoric notwithstanding, there are no guarantees on the ground that there is any willingness to protect the minority from the tyranny of the majority. Given this trend, the future will resemble the past.

These conclusions not only pose a problem in terms of the ability of individual state structures to adequately respond to the processes of globalization, but also in the context of whether the regional integration structures being embraced will succeed in mediating the experience of East Africans in the face of the globalizing East African region. The fact that some human rights issues necessary for engagement in globalisation have not been addressed in the manner required for participation means that internally much is yet to be done to entrench the processes and structures necessary for that engagement. In turn, this means that the regional structures of integration that are currently being created are standing on shaky ground because without appropriate intra-state structures firmly in place, the inter-state structures of regional integration are likely to achieve little success. If this is so, the conclusion will be irresistible, that on the regional framework, the future looks set to resemble the past of the unhappy experience of the collapsed East African Community.

The foregoing prognosis presents immense challenges to policy makers in the three East African states, especially with regard to laying the groundwork for integration. More specifically, it poses profound problems for the foreign policies of the states, and for the regional foreign policy that should emerge with the taking root of the process of regional integration. The point here is that while governments have a duty to create structures domestically that will enable the different states to engage with emerging processes and realities such as those of globalization, it is the task of foreign policy to explain those 
developments to the external world. It is also the primary challenge of foreign policy to explain, domestically and externally, the state's attitude towards contemporary global developments. In order to do this effectively, foreign policy ought to be grounded on sound domestic institutions, including those that promote human rights and encourage public dialogue about the foreign policy being pursued by states at any given time.

\section{Discourses on Human Rights and Foreign Policy}

There was consensus, particularly during the Cold War, that there is an inescapable tension between human rights and the foreign policies of states (Hill 1989). One reason for this was that the two fields had different but interdependent constituencies, so that the needs of one could be met only at the expense of the interests of the other. Human rights discourse also tends to open up states to outside scrutiny in what they consider to be their internal affairs. The issue that arises here is whether a state should pursue a human rights platform in its foreign policy even at the expense of opening itself up to internal scrutiny.

In the Cold War era literature, a case was made against enshrining human rights issues in foreign policy, since this tended to interfere with many concerns and interests of states in international affairs and in the world of practical diplomacy. It was argued that including human rights in foreign policy would affect negatively the promotion of good relations between states. It was also seen as impeding free trade and the flow of aid, as well as interfering with national security. For these reasons it was argued that human rights issues should remain a secondary concern to these pursuits of state (Vincent 1989; Vincent 1990).

Discourse on human rights and foreign policy is, however, not an entirely Cold War or western one. Instead, it has some resonance for all states that are grappling with defining a foreign policy platform which can both endure and make it distinct. In both cases however, a distinguishing feature has been the gap between what is professed in rhetoric and what is practiced. For example, post-Apartheid South Africa professed that human rights considerations were an integral part of her foreign policy, while in practice "South Africa was not going to base its choice of friends or the conduct of its foreign affairs on 
the human rights records of other countries" (Maluwa 2000, 251). The notion behind this was that the state's raison d'etat comes before all other considerations, including human rights.

The raison d'etat rationale needs to be seen in its contemporary context. In the old understanding, security meant physical security, and was concerned primarily with defense against threats emanating from outside. In the post-Cold War era however, security has come to embrace a wider set of issues and concerns, including environmental, social and health considerations. Security has also taken on a wider societal dimension, so that it embraces the safety of individuals, both physical as well as emotional. Thus security no longer means merely safety for the regime, nor even the effective protection of the state against external aggression, but also societal well being (Mwagiru 2008b). It not only harkens to the traditional notion of state sovereignty, but also to that of individual sovereignty (Annan 1999). The latter essentially implies that states should be instruments at the service of their peoples, and not vice versa (Annan 1999; Wolfers 1962).

Given this orientation, the question should no longer be, as some such as Doyle and Gardner (2003, 2) suggest, whether human rights and international relations are compatible. For, if states exist to serve the people, all those significant actions that states take, including security and foreign policy, are directed at the welfare of the people and not that of the regimes that run them. One of the most compelling arguments for this change in perspective is the principle that citizens are entitled to the promotion and protection of their human rights and welfare, and to exert pressure on governments to pursue those goals in the policies that they articulate, including foreign policy (Putnam 1988). This reflects the ideal future of the East African region.

However, some attention will need to be paid to the intra-state practice of linking foreign policy to human rights concerns. Inductivism leads to a very uneven picture in this regard. In the past, the record of East African states in having at least some human rightsdriven practices in their security and foreign policy has been mixed. In this respect, 
Uganda has had a poor record, in the sense that its policies seemed for a long time to be geared more towards obliterating human rights than protecting them. This was evident both in the unlamented Idi Amin and the second Obote regimes. Uganda during the Museveni era has tried to break from the experiences of the past, even though the experiences that can be observed make it difficult to conclude that the future will not be like the past. Tanzania provides a more interesting case study. The highlight of Tanzania's encounter with human rights rests significantly on its humanitarian intervention in Uganda that resulted in the toppling of Amin. That was in Tanzania's past. However, given the difficulties of generalizing from a single observation, it would be illadvised to conclude that Tanzania's future will be like its past.

The Kenyan case is even more complex. Much of the encounter with human rights issues in Kenya's foreign policy over the last thirty years has been confined to defending what was considered internationally to be a poor human rights record. In the past, this included political detentions and tortures that characterized the Kenyan experience particularly in the 1980s, as well as the infamous "land clashes" from the early 1990s. Generalizing from those experiences would lead to the conclusion that the future will be like the past. What is more, experience in the multi-party era does not compel a change of this generalization. Currently, threats of similar clashes are of great concern to citizens; and more than anything else, the subversion of the fight against impunity, the violent postelectoral conflict in 2008 and responses to them (Mwagiru 2008c) all reinforce the view that the future could well be like the infamous past.

\section{Conclusions: human rights, foreign policy and regional integration}

The foregoing discussion leads to the conclusion that there are inescapable linkages between human rights, foreign policy and regional integration. The processes of regional integration, seen against the reality of a globalizing world, provide important links among the three themes. Indeed, regional integration is the link that will enable East Africans to escape from the view that the future will be like the past, particularly in the context of the region's policies on human rights and foreign relations. 
The process of globalization requires that issues of human rights, foreign policy and regional integration be confronted afresh. Successful integration requires that the themes of foreign policy and human rights be woven into the wider process of regional integration. The inductivist method suggests that so far, generalizing from the past in terms of human rights and foreign policy, the regional integration process will confront obstacles. The main challenge is to discover how the cycle of inductivism can be broeken in a manner that allows the human rights and foreign policy future of East Africa to be shaped in a way that will lead the region to fulfilling its integration goals.

\section{References}

Abel, Reuben. 1976. Man is the Measure: A Cordial Invitation to the Central Problems of Philosophy. New York: The Free Press.

Annan, Kofi. 1999. "Two Concepts of Sovereignty". The Economist, $18^{\text {th }}$ September 1999.

Chweya, Ludeki. ed. 2002. Electoral Politics in Kenya. Nairobi: Claripress.

Coicaud, Jean-Marc, Michael Doyle and Anne-Marie Gardner. eds. 2003. The Globalisation of Human Rights. Tokyo: United Nations University Press.

De Senarclens, Pierre. 2003. "The Politics of Human Rights". In Coicaud, Jean-Marc et. Al. Eds. 2003, pp.137-159.

Doyal, Len, and Roger Harris. 1986. Empiricism, Explanation and Rationality: An Introduction to the Philosophy of the Social Sciences. London: Routledge \& Kegan Paul.

Doyle, Michael and Ann-Marie Gardner. 2003. "Introduction: Human Rights and International Order" In Coicaud, Jean-Mark et. Al. eds. 2003, pp.1-19.

Forsyth, David. Ed. 2000. Introduction to Human Rights and Comparative Foreign Policy. Tokyo: United Nations University Press.

Harris, Laurence. 2003. "The Dynamics of Globalisation: Eight Sceptical Theses". Ayitey, Ernest, Julius Court et. al. eds. Asia And Africa in the Global Economy. Tokyo: United Nations University Press, pp.23-39.

Hill, Dilys. 1989. "Human Rights and Foreign Policy: Theoretical Foundations". Hill, Dilys M. ed. Human Rights and Foreign Policy: Principles and Practices. London: Macmillan, pp. 3-20.

--. 1989. "Human Rights and Contemporary state Practice". In Hill, Dilys M. ed. 1989, pp. 21-41.

Hughes, John. 1990. The Philosophy of Social Research. New York: Longman.

Kuhn, Thomas. 1966. The Structure of Scientific Revolutions. Chicago: University of Chicago Press.

Lakatos, Imre. 1970. "Falsification and the Methodology of Scientific Research Programmes". Lakatos, Imre and Alan Musgrave, eds. Criticism and the Growth of Knowledge. Cambridge: Cambridge University Press, pp.91-196. 
Maluwa, Tiyanjana. 2000. "Human Rights and Foreign Policy in post-Apartheid South Africa". In Forsythe, David P. ed. 2000, Pp.250-275.

McGrew, Anthony. 1992. "Conceptualising Global Politics". McGrew, Anthony and Paul Lewis, eds. Global Politics: Globalisation And the Nation-State. Cambridge: Polity Press, pp.1-28.

Modelski, George. 1974. Principles of World Politics. New York: The Free Press.

Munene, Macharia. 2001. The Politics of Transition in Kenya. Nairobi: Quest \& Insight Publishers.

Munz, Peter. 1985. Our Knowledge of the growth of Knowledge: Popper or Wittgenstein? London: Routledge \& Kegan Paul.

Mwagiru, Makumi. 2006. "The Constitution was Ours before We Were the Constitution's: Reflections on the Constitutional Debates in Kenya". Oketch, Emma, Luis Franceschi and Paul Mimbi. eds. Politics and the Common Good. Nairobi: Strathmore University Press, pp.186-206.

--. 2008a. "Globalisation and African Foreign Relations: Historical and Intellectual Antecedents". Revue Universitaire de Djibouti, 5, 2008, pp.115-138.

--. 2008b. Human Security: Setting the Agenda for the Horn of Africa. Nairobi: IDRC/APFO.

--. 2008c. The Water's Edge: Mediation of Violent Electoral Conflict in Kenya. Nairobi: IDIS.

Popper, Karl. 1980. The Logic of Scientific Discovery. London: Unwin Hyman.

Putnam, R.D. 1988. "Diplomacy and Domestic Politics: The Logic of Two-Level Games". International Organisation, 42, 1988, pp.427-460.

Russell, Bertrand. 1980. The Problems of Philosophy. Oxford: Oxford University Press.

Stern, Geoffrey. 2000. The Structure of International Society. London: Pinter.

Vasquez, John. 1983. The Power of Power Politics. London: Pinter.

Vincent, R.J. 1989. "Human Rights in Foreign Policy". In Hill, Dilys M., ed. 1989, pp.54-66.

--. 1990. Human Rights and International Relations. Cambridge: Cambridge University Press.

Wanyande, P., M. Omosa \& Ludecki Chweya. Eds. 2007. Governance and Transition Politics in Kenya. Nairobi: Nairobi University Press.

Wolfers, Arnold. 1962. Discord and Collaboration. Baltimore: Johns Hopkins University Press. 